\title{
CP-titanium and titanium alloys as an alternative material to dental gold-silver-palladium alloys for crown restoration
}

\author{
WADA Kenichi KUROIWA Akihiro*
}

Keyword : Cp-Ti, Ti alloy, CAD-CAM

\begin{abstract}
In recent years, the cost of manufacturing prosthetic devices has increased due to soaring prices of palladium and gold, and as a result, health insurance financing is under pressure. As one countermeasure, a dental CAD-CAM hybrid resin was adopted in 2014 as a treatment option only for premolar crown restorations. In 2020, the indications for this hybrid resin were expanded to the maxillary and mandibular first molars. This enabled crown restoration for metal allergy patients or patients with esthetic demands, and we were able to respond to the increasing prices of precious metals. Considering the long-term prognosis, however, it is unknown whether hybrid resin crowns have optimal mechanical properties as an alternative material for molar crown restoration. In comparison with noble metals, $\mathrm{CP}$-titanium and titanium alloys ( $\mathrm{Cp}$-Ti and $\mathrm{Ti}$ alloys) are inexpensive metals that have mechanical strength similar to that of Type 4 gold alloy. Laboratory techniques for dental gold alloys can be also applied for $\mathrm{Cp}$-Ti and $\mathrm{Ti}$ alloys. Thus, cast crowns made with $\mathrm{Cp}$ - $\mathrm{Ti}$ and $\mathrm{Ti}$ alloy became covered by national insurance for medical devices in 2020. However, titanium casting requires complicated procedures with technically sensitive points. Therefore, application of CAD-CAM for the fabrication of $\mathrm{Cp}$-Ti and Ti alloy prosthetic devices may be a solution to the problems in titanium casting. The present review proposes adopting CAD-CAM for the fabrication of titanium crowns under national insurance coverage in order to stably supply highly accurate titanium crowns to dental professions.
\end{abstract}

[The Journal of the Academy of Clinical Dentistry 40 (3) : 231-237, 2020]

\section{Introduction}

Since W. H. Taggart invented the dental casting of gold alloy inlays in 1907, the lost-wax method has been examined for precision casting of crown prosthetics. Although the prosthetic device for crowns is supposed to be made of cast gold alloys, gold-silver-palladium alloys are used as a substitute due to cost limitations in Japan's health

Wada Dental Clinic 2454-27 Tadokoro Shioya-machi, Shioya-gun, Tochigi-ken 329-2331 Japan

*Department of Prosthodontics, School of Dentistry, Matsumoto Dental University

reception: $2020 / 6 / 25$ acceptance: $2020 / 8 / 24$ insurance system. The current composition ( $\mathrm{Au}: 12 \%, \mathrm{Ag}$ : 45-52\%, Pd: $20 \%$, and $\mathrm{Cu}: 12-20 \%)$ of gold-silver-palladium alloy was specified and has been used since 1980 . In recent years, the prices of gold and palladium have continued to increase worldwide, and the price of dental casting $12 \%$ gold-silver-palladium alloys (hereinafter referred to as "gold-palladium") has increased two- to three-fold compared with a few years ago. Thus, materials made of precious metals are not appropriate for medical treatment under universal coverage because of their high variability influenced by the global economy. At the 2002 annual meeting of the Japanese Society for Dental Technology, 20 panelists advocated the problems with gold-palladium and possible alternative metals have been sought since ${ }^{1)}$. 
Titanium, which was considered "promising" as an alternative metal, has only been used for metal dentures and crown prosthetic devices for patients with metal allergies because of the difficulty in precision casting compared with gold-palladium. However, due to its excellent properties ${ }^{2-4)}$, and low and stable price, it was adopted as a material used in treatment under universal coverage in 2020. However, titanium casting is cumbersome and technically sensitive. In this report, we propose the use of $\mathrm{Cp}$ - $\mathrm{Ti}$ and Ti alloys as designated dental materials in conjunction with computer-aided manufacturing (CAM) technology.

\section{Problems in Titanium Casting}

Titanium, when passive film is formed, has excellent corrosion resistance, chemical stability, and biocompatibility. These characteristics make it suitable as a biomaterial. In terms of mechanical strength, $\mathrm{Cp}$-Ti has a tensile strength of 275-735 $\mathrm{MPa}$ (JIS Class 1-4) and that of Ti alloy (Ti-6Al-4V) is $620-1800 \mathrm{MPa}$, which is sufficient for dental use. Although it has excellent properties, titanium has not been popularized as a casting metal due to:

(1) High melting point $\left(1668^{\circ} \mathrm{C}\right)$;

(2) Vulnerability to contamination-a small number of elements can greatly change the mechanical properties of the material;

(3) Cavity (hollow) -shaped casting defects may develop; and

(4) Difficulty in polishing.

In order to solve these problems, the following measures are necessary:

\section{Special casting machine is required (1) and (2))}

First, a special heat source using high-frequency waves or arc discharge is used to melt high-melting-point titanium. In addition, at room temperature, titanium acquires a passive film on its surface due to the formation of an oxide film and is chemically highly stable, but it absorbs oxygen and becomes hard and brittle when melted in air. Indeed, during the melting of titanium, the melting chamber is filled with an inert gas (Ar) to prevent oxidation reactions. For this reason, special and expensive casting machines ${ }^{5)}$ are required. Considering the dental technical engineering process, it is cumbersome and impractical to group-purchase this kind of machine in the same manner as current CAD-CAM machines to build machining centers.

\section{Special investing materials are required (1) and (2))}

Casting requires a mold in which the molten metal flows and is shaped. As high-melting-point titanium decomposes and reacts with $\mathrm{SiO}_{2}$ and $\mathrm{Mg}_{3}\left(\mathrm{PO}_{4}\right)_{2}$, the oxides, such as $\mathrm{ZrO}_{2}, \mathrm{Al}_{2} \mathrm{O}_{3}$, and $\mathrm{MgO}$, are used as refractory materials ${ }^{6)}$. In the past, special oxides, such as $\mathrm{CaO}$ and $\mathrm{Y}_{2} \mathrm{O}_{3}$, were investigated to further reduce reactivity ${ }^{7)}$. Inevitably, the use of special investing materials leads to higher costs for casting, but the cost may be reduced when titanium casting becomes common.

\section{Casting defects are inevitable (3)}

This is the biggest factor hindering its popularization. Although casting precision improves with higher mold temperatures, the lower-temperature mold is used because the higher the mold temperature, the easier it is for the mold to react with titanium. As a result, the time available for the molten metal to properly fill the casting chamber becomes markedly short and the molten metal solidifies while flowing into the chamber. Furthermore, the flow of the molten metal is also different from that of other metals $^{8)}$. In addition, due to the low density of metal, internal defects specific to titanium casting ${ }^{9)}$ occur unless the timing of pressure application, air permeability of the mold, and design of the sprue that feeds the molten metal are adjusted in gas pressure casting ${ }^{10)}$. These are the challenges in titanium casting. Being a light metal, titanium has high x-ray penetration and is easy to be nondestructively inspected; therefore, radiographic inspection of castings, which has not been performer before, became possible. Due to the complexity of preventing casting defects, titanium was considered to be an inexpensive but difficult material to handle.

\section{Grinding (4)}

The high temperature of molten metal easily decomposes refractory materials and the high reactivity of titanium at high temperatures makes it easy to react with ambient components. The reaction layer $(\alpha$-case $)$ formed on the surface after casting was hard and difficult to remove, and required a long polishing time to achieve a metallic luster ${ }^{11}$, 12) . The thickness of the reaction layer ranged from 25 to $100 \mu \mathrm{m}^{13)}$ and consisted of four layers ${ }^{14)}$. As the morphology of the prosthetic device changes if the reaction layer is completely removed, development of a refractory material with low reactivity was focused on to improve the polishability of cast titanium.

\section{Misconceptions about titanium}

Another problem that has hindered its spread is its hardness. At the beginning of its development, titanium reacted easily at high temperatures; therefore, it reacted with oxygen at the time of melting and with the constituent elements of the investing material, forming a hard layer on the surface. For this reason, the material was rated as hard and difficult to handle. Subsequently, when lower reactive investment materials were developed, titanium was considered to be lower in strength than expected. This contradictory mechanical nature of cast titanium puzzled clinicians. As titanium casts were difficult even for dental technicians to supply to dental clinics, there was no indication for which cast titanium was better than the easy-to-use goldpalladium alloys or Co-Cr alloys, which have excellent mechanical properties as cast partial dentures. As a result, titanium gained popularity in use in dental implants fabricated by CAM from $\mathrm{Cp}$-titanium and titanium alloys, rather than in a cast prosthesis. Thus, the machined titanium products we recommend in this review have been used in the oral cavity for a long period of time. 


\section{Application of CAD-CAM Crowns to Crown Prosthetics}

1. CAD-CAM crowns made with hybrid resin (hereinafter referred to as "resin")

CAD-CAM crowns made with resin were first covered by national insurance for the bicuspids in 2014, then for molars of metal allergy patients in 2016, and further to the maxillary and mandibular first molars in 2020 under the condition that a healthy second molar is present. However, in order to strengthen the prosthetic device with resin, sufficient clearance between the abutment and opposing tooth is required to obtain a sufficient thickness of the crown. This requires a large amount of tooth preparation for resin crowns. Consequently, the resin crowns must be cautiously applied to vital teeth. As resin blocks for CAD-CAM crowns have a high degree of polymerization and a dense cross-linked structure, which makes them a disadvantage in strong bonding, there are many reports of them falling out ${ }^{15)}$.

\section{Problems with the use of resin for molar restora-} tion

The molar is the keystone of occlusal support. Excessive occlusal force is constantly loaded on the molar and mortar motion is also subjected during occlusion. The currently developed resins have improved compressive and flexural strength by increasing the filler content and the degree of polymerization, but their mechanical properties are hard and brittle ${ }^{16)}$. In order to maintain a stable jaw position, it is necessary to have not only instantaneous strength, but also higher toughness. The long-term use of resin CAD-CAM crowns on molars, even under restricted conditions, remains a matter for reconsideration.

\section{CAD-CAM processing of titanium}

It was previously reported that there is no difference in adaptability between long-term and short-term implantsupported bridges made of titanium using the CAD-CAM method $^{17)}$. The adaptability of crowns was reported to be $\pm 80 \mu \mathrm{m}$ for the casting method and $\pm 15 \mu \mathrm{m}$ for the machining method ${ }^{18)}$. The cement film thickness at the crown margins was $51.6 \pm 28.1 \mu \mathrm{m}$ and that on the inner surface was $35.9 \pm 14.7 \mu \mathrm{m}^{19)}$. Full crowns made by machining

\section{References}

1) Ito $\mathrm{Y}$, Eto $\mathrm{T}$, Gionahaku $\mathrm{N}$, et al:: Substitute Materials for Ag-Pd-Au Alloy in the Health Insurance System in Japan. J Jpn Prosthodont Soc, 46 (5): 634-638, 2002 (in Japanese).

2) Koizumi $H$, Takeuchi $Y$, Imai $H$, et al: : Application of titanium and titanium alloys to fixed dental prostheses. J.P.R., 63: 266-270, 2019.

3) Takeuchi Y, Tanaka M, Tanaka J, et al.: Fabrication systems for restorations and fixed dental prostheses made of titanium and titanium alloys. J.P.R., 64: 1-5, 2020. were compared with those made by casting, and the CADCAM specimen had sufficient machining accuracy ${ }^{20)}$. Titanium crowns made by casting better fit the margins than those made by CAD-CAM. The fit was particularly poor for the knife-edge geometry, and the gap was significantly smaller for the shamfer and shoulder margins than for the knife-edge margin ${ }^{21)}$.

Thus, the accuracy of CAD-CAM machining of titanium has been confirmed, and although the margin should be in the form of a shamfer to facilitate machining, no problem in clinical application was found.

\section{Problems with processing machines}

In recent years, most dental CAD-CAM machines are dry-type machines for grinding zirconia and hybrid resin. Lubrication for cooling (wet process) is required when cutting metal, and the current wet process machines are large and expensive. There are only a few laboratories that have this system for metal cutting. However, the recent development of CAD-CAM network systems has made it possible to solve such problems by outsourcing to a machining center at the end of the design process without having to purchase individual machines.

\section{Conclusion}

The accuracy of CAD-CAM machining on titanium has been sufficiently demonstrated. CAD-CAM machining is not prone to technical sensitivity.

The machining of titanium has been used in the production of implants and has a high level of biological safety. As the mechanical properties of titanium are similar to those of gold alloys, the accumulated clinical experience with gold alloys can be utilized.

For the above reasons, covering $\mathrm{Cp}$ - $\mathrm{Ti}$ and $\mathrm{Ti}$ alloys as materials for posterior crowns and bridges made by the CAD-CAM method under the national insurance is recommended.

This study was supported in part by grants from the Japanese Dental Science Federation (JDSFDSP1-2019-211-1) and Japanese Association for Dental Science (Sponsored Research 2019).
4) Nihei T, Ohashi K, Hattori M, et al.: A surveillance study of the demand of titanium and titanium alloys in Japan. D.M.J., 39: 9-11, 2020.

5) Takahashi J, Zhang J Z, Okazaki M: Effect of Casting Methods on Castability of Pure Titanium. D.M.J., 12: 245252, 1993.

6) Ida K, Togaya $\mathrm{T}$, Tsutsumi S, et al.: Effect of Magnesia Investments in the Dental Casting of Pure Titanium or Titanium Alloys. D.M.J., 1: 8-21, 1982.

7) Takahashi H, Murakami M, Fujyu T, et al:: Basic 
Researches for Titanium Cast Crown Using Calcia Investments. J Jn Prosthodont Soc, 35: 923-930, 1991. (in Japanese)

8) Watanabe K, Okawa S, Miyakawa O, et al.: Molten Titanium Flow in a Mesh Cavity by the Flow Visualization Technique. D.M.J., 10: 128-137, 1991.

9) Reza F, Takahashi H, Iwasaki Na, et al.: Effects of investment type and casting system on permeability and castability of CP titanium. J.P.D., 104: 114-121, 2010.

10) Kuroiwa A, Igarashi Y: Application of Pure Titanium to Metal Framework J Jpn Prosthodont Soc, 42: 547-558, 1998. (in Japanese)

11) Kawai Y, Takayama Y, Abe M, et al.: Study of polishing steps for titanium castings. Tsurumi Univ Dent J, 23: 407418, 1997. (in Japanese)

12) Hirata $T$, Nakamura $T$, Takashima $F$, et al: Studies on polishing of $\mathrm{Ti}$ and $\mathrm{Ag}-\mathrm{Pd}-\mathrm{Cu}-\mathrm{Au}$ alloy with five dental abrasives. J Oral Rehabil, 28: 773-777, 2001.

13) Kuroiwa A, Wada K, Hibino Y, et al.: Studies on Titanium Casting (Part 1)-Influence of the Mold Temperature on Titanium Castings-. Shika Zairyo Kikai, 9: 279-288, 1990. (in Japanese)

14) Miyakawa O, Watanabe $\mathrm{K}$, Okawa $\mathrm{S}$, et al.: Layered Structure of Cast Titanium Surface. D.M.J., 8: 175-185, 1989.
15) Shinya A, Miura S, Koizumi H, et al.: Current status and future prospect of CAD/CAM composite crown. Ann Jpn Prosthodont Soc, 9: 1-15, 2017. (in Japanese)

16) Kameyama $Y$, Ohashi $K$, Yamaguchi $H$, et al.: Mechanical properties of hybrid resin blocks for CAD/CAM crown. Shika Zairyo Kikai, 36: 453-459, 2017. (in Japanese)

17) Joannis K, Philipp M, Regina SM, et al.: CAD/CAM fabrication accuracy of long- vs. short-span implantsupported FDPs. Clinical oral implants research, 26: 245249, 2015.

18) Negishi M, Takebe S, Kanda T, et al.: Mechanical Properties and Dimentional Properties of Titanium in Casting and Machining. Meirinshika gikougaku zatsushi , 2: 22-27, 1999. (in Japanese)

19) Ohta R, Marutani Y, Shiba A, et al:: Fit of Pure Titanium Crown Manufactured by Commercial Dental CAD/ CAM System. Shouwa shigaku, 24: 172-178, 2004. (in Japanese)

20) Ohno T, Kuroiwa A: Effect of Differences in Fabrication Methods for Pure Titanium Crown Restoration on Fitness. Shika Zairyo Kikai, 20: 287-299, 2001. (in Japanese)

21) Hyun HS, Yang HS, Lim HP, et al:: Marginal accuracy and internal fit of machine-milled and cast titanium crowns. J Prosthet Dent, 106: 191-197, 2011.

\title{
$12 \%$ 金銀パラジウム合金製歯冠補綴装置の代替材料としての CAD-CAM による Cp チタン・チタン合金の利用
}

\author{
和田賢一 黒岩昭弘 * \\ キーワード : Cp チタン, チタン合金, CAD-CAM
}

近年，パラジウムや金の高騰によって補綴装置の作製コストが上がり，健康保険財政を圧迫している．その対応の一つ として，2014 年に歯科用 CAD-CAM システムを用いたハイブリッドレジンによる歯冠補緅が保険収載に導入された，初 期には小歯部のみの応用であったが, 2020 年までには上下顎の第一大臼歯まで適応が拡大された．このようにして金 属アレルギー患者への治療や審美的要求, そして高騰する金属材料費への対応としての目的は達成されたが, 長期的な対 応としてレジンの機械的性質の制約を考慮すると大自歯への応用は慎重にするべきである，一方，Cpチタンやチ夕ン合 金は廉価であり，Type4 金合金と同程度の機械的強度を有する。ゆえに各種補緅装置に関してはこれまでの金合金の経 験を活かすことができる。これらの有用性をもとに 2020 年の医療機器に係る保険適用として全部金属冠（鋳造）用に純 チタンが採択された。しかしながら著者はいまだにチタン鋳造は煩雑で技術依存度が高いと考える．これを解決するには CAD-CAMによって Cp チタンやチタン合金による補綴装置を作製することである．誰でも精度の良い装置を安定に供 給する目的で CAD-CAM システムを用いた金属冠として Cp チタン・チタン合金を保険適用とすることを提案したい 
はじめに

歯冠補経物を精密鋳造法にて製作する技法は, W.H.Taggart が金合金インレーの歯科鋳造を 1907 年に 考案され以来, 精密な鋳造体を求めて, 長い間ロス卜 ワックス法を用いて開発・研究がされてきた。 さて, 教 育や理論的に歯冠補綴装置は金合金を鋳造して製作する ことを前提にされているが，金合金を国民健康保険に 用いるには製作コストがかかりすぎるのでパラジウム 合金が代用合金に用いられている。初期には $20 \%$ の金 を含有した時期もあったが, 学術的・経済性・機械的 強度から 1980 年以降, 現在の規格 $(\mathrm{Au}: 12 \cdot \mathrm{Ag}: 45-52$ ・ $\mathrm{Pd}: 20 \cdot \mathrm{Cu}: 12-20 \%)$ となった. 近年, 金やパラジウム の世界的な高騰が続いており，歯科鋳造用 $12 \%$ 金含有 金銀パラジウム合金（以下金パラと略す）は数年前の価 格から 2-3 倍となっている.この様な貴金属を主材とし た材料は世界経済の影響から変動が大きく, 診療報酬が 一定の保険診療の材料としては適切でなく, 原料価格の 安定した代替材料が望まれる。すすでに 2002 年に日本歯 科理工学会では 20 名のパネリストによって金パラに対 する問題提起が報告され，代替金属が模索されていた ${ }^{11}$.

さて，これまで代替金属として有望であったチタンは 金パラに比べ鋳造が困難であったので, 金属床義歯や金 属アレルギー患者に対応する歯冠補綴装置として使われ てきた. しかしながら優れた特性が紹介され 2 4) 安価 で安定した金属の価格などから 2020 年には医療機器に 倸る保険適用に採択された。ところが，著者はいまだ にチタン鋳造は煩雑で Technic Sensitive であると考える. そこで誰でも精度の良い装置を安定に供給することを目 的に, CAD-CAMによって Cpチタンやチタン合金を加 工した補緅装置を保険に定要することを提案する。

\section{II チタン鋳造の問題点}

チタンは低比重で不導体膜を形成すると溶出しにくく 耐食性に優れ，化学的に安定で生体親和性に優れる。こ れらの特性から生体材料として適した性質を持つ。また， 機械的強度は $\mathrm{Cp}$ チタンで引張り強度 275-735MPa（JIS 第 1-4 種), チタン合金 (Ti-6Al-4V) で 620-1800MPa と歯科用として十分な強度を持つ. 良好な性質を持つの にも関わらず，鋳造用金属として普及しなかった理由は，

(1) 融点が高い $\left(1,668^{\circ} \mathrm{C}\right)$

(2)極少量の元素の混入で機械的性質が大きく変化
する.

(3)空洞状の欠陥が発生しやすい.

(4)研磨が困難である.

が挙げられる。 これらの問題を解決するために

\section{1. 特殊な鋳造機が必要 (1), (2)}

まず，高融点なチタンの溶解には高周波やアーク放 電を用いた特殊な熱源が必要となる。加えて, チタンは 常温域では表面の酸化皮膜の生成により不導体皮膜を獲 得し，化学的に非常に安定であるが，大気中で溶解する と酸素を吸収して硬く脆くなる，実際，チタンの融解時 には溶解室を不活性ガス（Ar）で置換して反応を防い でいる．このため特殊で高価な鋳造機が必要となる 5). これを今日の CAD-CAM の加工機のように共同購入や 加工センター化することは技工操作上煩雑であり，現実 的ではない.

\section{2. 特殊な埋没材が必要（1), (2)}

鋳造には溶けた金属が流れ賦形される鋳型が必要で ある. 高融点なチタンは $\mathrm{SiO}_{2}$ や $\mathrm{Mg}_{3}\left(\mathrm{PO}_{4}\right)_{2}$ を分解し反 応するため, 耐火材には $\mathrm{ZrO}_{2}, \mathrm{Al}_{2} \mathrm{O}_{3}, \mathrm{MgO}$ を用いて いる6) 過去には更に反応性を抑えるために $\mathrm{CaO}, \mathrm{Y}_{2} \mathrm{O}_{3}$ などの特殊な酸化物を検討した時期もあった ${ }^{7)}$ 。必然的 に特殊な埋没材は高コストになるが，普及すれば安価に なる可能性はある.

\section{3. 鋳造欠陥の発生 (3)}

これが普及を妨げた大きな問題である．鋳造性を向上 させるには鋳型温度が高いほど良いが，鋳型温度が高い ほど鋳型とチタンの反応が高くなるので，低温鋳型が使 われるようになったすると溶湯が鋳窝を適切に充填す る時間は極端に短くなり溶湯は流入しながら凝固すると 言われ，さらに金属溶湯の流れもこれまで金属と異なっ ていることが判明している ${ }^{8)}$. 加えて，金属の密度が低 いのでガス圧鋳造などでは圧をかけるタイミングや鋳型 の通気性 ${ }^{9)}$, 金属溶湯を流すスプルーのデザインなどを 考慮しないとチタン鋳造独特の空洞状の内部欠陥が多発 した ${ }^{10)}$. クラスプの外観が再現されていても折れた原 因がこれであり，チタン鋳造が難しいと言われた所以で ある。また，軽金属であるチタンはエックス線の透過性 が高く非破壊検査がしやすいので，それまで行われてい なかった鋳造体のエックス線写真による検查が行われた。 鋳造欠陥の予防に関する煩雑さもあり，金属は安くても 扱いにくい材料とされた。 


\section{4. 研磨 (4)}

金属溶湯の温度が高いので耐火材を容易に分解し， なおかつ高温時のチタンの活性は高く反応しやすい. 鋳 造後, 表層に形成された反応層（ $a$ ケース）は硬く, 除 去が困難で金属光沢を得るまでの研磨に時間を要し た 11，12）。応層の厚さは 25-100 $\mu \mathrm{m}$ におよび 13)，そ れは 4 層からなる ${ }^{14 ）}$.この反応層を完全に除去すると 補綴装置の形態が変化するので, 研磨を良くするために 反応性の低い耐火材の開発に傾注していった。

\section{5. チタンに対する誤解}

もう一つの普及を妨げた問題である。開発当初, チ夕 ンが高温時に反応しやすいので, 溶解時の酸素や埋没材 の構成元素と反応し, 表面に硬い層が形成され研磨に多 くの時間を要した. これから, 硬く扱いにくい材料と評 価された. その後, 反応しにくい埋没材が開発されると チタンは思ったよりも強度がないとされた.この矛盾し た機械的性質の評価が臨床家に戸惑いを感じさせた，供 給する側の技工士も鋳造が難しかったので，作性の良い 金パラやキャストパーシャルとして良好な機械的性質を 持つ Co-Cr 合金を凌駕する適応症を見いだせなかった。 結局, チタンが最も普及したのはインプラント材料とし てで, それらは $\mathrm{cp}$ チタンやチタン合金の削り出しであ る. 今回, 我々が推奨しょうとしている削り出しの加工 品はすでに口腔内で長期間使われている.

\section{CAD-CAM 冠の歯冠補緅物への利用}

1. ハイブリッドレジン（以下レジンと略す）による CAD-CAM 冠

レジンにより製作されたCAD-CAM 冠は 2014 年に まず，小臼歯のみに適応が認められ，2016年に金属ア レルギーを有する患者の大臼歯部に適応, 2020 年には 健全な第二大兒歯が現存することの条件が付加され, 上 下顎第一大臼歯部までに拡大された。しかしながら、レ ジンで補綴装置の強度を得るには対合歯との十分なクリ アランスが必要なため形成量が多い。 また，有髄歯への 適応にも慎重にならざるを経ない. CAD-CAM 冠用レ ジンブロックは, 強度を得るために高い重合度, 網目状 の架橋構造を呈するので接着には不向きな性質となり脱 落の報告が多い15).

\section{2. 大臼歯へのレジン適応}

大臼歯は咬合支持を支える要な歯である，大臼歯には 絶えず過大な咬合圧が掛かり，機能時には臼磨運動も加 わる. 現在開発されているレジンはこれに対応すべく フィラーの含有率や重合度を上げ，圧縮強さや曲げ強さ を向上させているが，硬く脆い傾向がある 16). 安定し た顎位を保つには瞬間的な強さだけではなく高い勒性を 持つことが必要である. やはり限局した条件下への適応 としても大臼歯にレジン CAD-CAM 冠を長期に用いる ことは再考の余地がある.

\section{3. チタンの CAD-CAM 加工 \\ チタンをCAD-CAM にてロングスパンとショートス} パンインプラント支持ブリッジを製作し適合を比較し たところ適合度の差はないと報告している ${ }^{17)}$. 加工方 法で比較した場合, 鋳造加工法では $\pm 80 \mu \mathrm{m}$, 機械加工 法では土 $15 \mu \mathrm{m}$ であった ${ }^{18)}$. クラウンのマージン部の セメント被膜厚さは $51.6 \pm 28.1 \mu \mathrm{m}$ であり, 内面のセメ ント被膜厚さは $35.9 \pm 14.7 \mu \mathrm{m}$ であった ${ }^{19)}$. 機械加工 と鋳造により作製されたフルクラウンを比較したところ, CAD-CAMによって作製された試験片は, 十分な加工 精度を有する 20）。鋳造によるチタンクラウンはCADCAMよりマージンの適合性が高い. 特にナイフエッ ジで適合が悪く, シャンファーとショルダーマージン は, ナイフエッジマージンよりも間隙は有意に小さかっ た21).

このようにチタンの CAD-CAM 加工による精度が検 証されており，マージンは機械加工しやすいようにシャ ンファー形態にする点に留意すべきであるものの, 臨床 での使用に問題ないと判断できる.

\section{4. 加工機に関する問題}

近年の歯科用 CAD-CAM で使われている加工機は, ジルコニアやハイブリッドレジンなどを削る乾式タイプ が多い. 金属の切削には冷却用の注油（湿式）が必要で, 現在ある湿式は機械自体が大きく高価なことが欠点であ る. 金属の削り出し用として導入した技工所も少ない. しかしながら, 近年の CAD-CAM のネットワークシス テムの発達から個別に加工機を購入しなくても設計が終 わった時点で加工センターにアウトソーシングすれば解 決する. 
まとめ

チタンにおける CAD-CAM 加工精度は十分検証され ている.

CAD-CAM による加工には Technic Sensitive が発生 しない.

加工品としてインプラント体の実績があり, 生体安全
性は高い。

機械的性質は金合金に近似するのでこれまでの臨床経 験の含蓄が生かせる.

以上の理由から Cp チタン・チタン合金を CAD-CAM により製作した臼歯部の歯冠補経装置や架橋義歯を保険 採用することを提案する。

\section{参考文献解説}

1）高騰した金銀パラジウム合金の価格が社会保険における診 療報酬を圧迫した. 現在 (2002)のところ, 社会保険に適用さ れる合金として, $12 \%$ 金銀パラジウム合金に匹敵するほかの 材料を見いだすことは困難である. 今回の論議は最良の材料 を純粋に考えるためのよい機会と報告

2）総説：チタンの機械的性質, 鋳造性, 耐食性, チタン合金は, 従来の歯科用合金と同等またはそれ以上である. 臨床では, チタンとTi-6Al-7Nb合金は臨床に適していると報告.

3）総説：さまざまなシステムで製作されたチタンとチタン合金の修 復物と固定補綴物の辺縁と内部の適合性は臨床的に許容さ れる範囲内だった. チタンとチタン合金は, 現在使用されてい る歯科用金属の有望な代替品であることを示唆.

4）総説: パラジウムの高騰のために代替金属の選択が必要であ る. チタン・チタン合金は加工技術が整ってきてパラジウム合金 と近似した精度なので代替材料として検討する価值がある.

5） 溶解室と鋳造室が別れた加圧吸引鋳造機, 分れていない圧 力式鋳造機, 遠心式鋳造機にてチタンの鋳込率を比較したと ころ遠心鋳造法が最も良い值を示した.

6） 反応性を抑えるために $\mathrm{MgO}$ 基材とした埋没材を使用したと ころ, 良好な鋳造体を得ることができた。

7） 反応性を抑えるためにCaOを鋳型に用いて鋳造を行った. 污 染の程度が少ないため, 特別な手法を用いなくても調整研磨 が可能であった。

8） EPMAによる標点元素法を用いてチタンの湯流れを可視化, 独特な湯流れを確認した. 圧力鋳造機を使用した場合,メッ シュ内部は凝固層で構成され,流れが層流である.遠心鋳造 機では流れが不規則であり, 乱流が発生した. メッシュパター ンなどの複雑なキャビテイでは, 遠心力ではなく圧力が有効な 鋳造力であった.

9）通気性の異なる埋没材を用いて鋳込率を確認した. 良好な 通気性があってもチタンの鋳込率は向上せず高い鋳造力に て十分な臨床結果が得られる。

10）異なった鋳造方法·鋳型温度・鋳造圧・通気性にて鋳込率を 確認,空洞状の欠陥の予防策としてのスプルーイングを紹介, 生産コストなどを紹介しながらチタンの将来を示唆した.

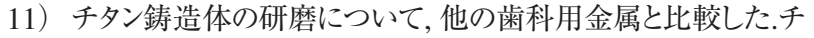
夕ン試料最終研磨面の中心線平均粗さは,平均 $0.37 \mu \mathrm{m}$ で
あった. チタン試料の最終研磨面の表面性状は, 他の歯科用 金属と比較してもほぼ遜色の無いものと報告。

12） Tiとパラジウム合金の研摩を比較した. Tiは研磨が困難で研 磨剂の頻繁な交換が必要. Ti用の新しい研磨剤の開発が必 要する.

13）鋳型が室温の場合,反応層は約 $25 \mu \mathrm{m}$, 鋳型温度が $900^{\circ} \mathrm{C} の$ 場合, 約 $100 \mu \mathrm{m}$ の幅で確認され, 鋳型温度によってチタンの 機械的性質は変わり, 特に影響を受けるのは表面の硬さであ ると示唆.

14）リン酸塩を結合剂とし，アルミナハリリを耐火材とする鋳型に チタンを鋳造した. 鋳造体の表層構造をEPMAによって調べ, それが4層からなることを明らかにした。

15）小臼歯の全部被覆冠として保険収載されたCAD/CAM 冠 の脱落などに代表されるトラブル報告について問題提起. 支 台歯形態や接着方法に独自の配慮が必要であるとした.

16）無機フイラー含有量に対する曲げ強さ, 摩耗量および表面硬 さとの相関関係を分析した結果, 摩耗量は有意な負の相関, 表面硬さでは有意な正の相関を認めたが, 曲げ強さとは相関 が認められなかった. セラミックスに似た傾向を示すブロックの ことも指摘している.

17）チタンをCAD/CAMにてインプラント支持のロングスパンと ショートスパンブリッジの適合精度を比較したところ適合に差 がないと報告。

18）チタンの加工精度は鋳造加工法では $80 \mu \mathrm{m}$, 機械加工法で は土15 $\mu \mathrm{m}$ であった. また表面あらさは機械加工法が鋳造加 工法より小さい数值を示した. 研磨作業性についても機械加 工法に優位性が認められた。

19）純チタンクラウンのマージン部のセメント被膜厚さは $51.6 \pm 28.1 \mu \mathrm{m}$ であり, 内面全体のセメント被膜厚さは35.9 $14.7 \mu$ mであった.

20） $\mathrm{CAD} / \mathrm{CAM}$ にる機械加工と鋳造により作製されたフルクラウ ン型試験片の適合度を比較検討した. 歯科用CAD/CAMに よって作製された試験片は, 十分な加工精度を有することが 確認された

21）鋳造製チタンクラウンはCAD/CAMよりマージンの適合性が 高い. ナイフエッジが適合が悪く, シャンファーとショルダーマー ジンは,ナイフエッジマージンよりも間隙が有意に小さかった。 